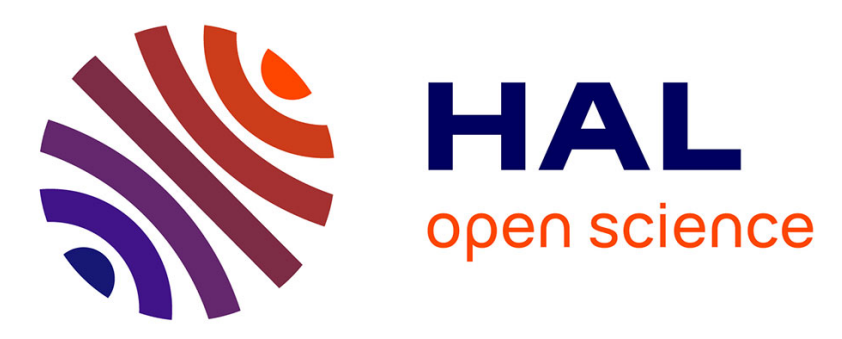

\title{
Simulation of the infrared signature of transient luminous events in the middle atmosphere for a limb line of sight
}

Frédéric Romand, Laurence Croizé, Sébastien Payan, Nathalie Huret

\section{- To cite this version:}

Frédéric Romand, Laurence Croizé, Sébastien Payan, Nathalie Huret. Simulation of the infrared signature of transient luminous events in the middle atmosphere for a limb line of sight. EGU General Assembly 2016, Apr 2016, Vienne, Austria. insu-03573530

\section{HAL Id: insu-03573530 \\ https://hal-insu.archives-ouvertes.fr/insu-03573530}

Submitted on 15 Feb 2022

HAL is a multi-disciplinary open access archive for the deposit and dissemination of scientific research documents, whether they are published or not. The documents may come from teaching and research institutions in France or abroad, or from public or private research centers.
L'archive ouverte pluridisciplinaire HAL, est destinée au dépôt et à la diffusion de documents scientifiques de niveau recherche, publiés ou non, émanant des établissements d'enseignement et de recherche français ou étrangers, des laboratoires publics ou privés.

\section{(c)(1)}

Distributed under a Creative Commons Attribution| 4.0 International License 


\title{
Simulation of the infrared signature of transient luminous events in the middle atmosphere for a limb line of sight
}

\author{
Frédéric Romand (1,2), Laurence Croizé (1), Sébastien Payan (2), and Nathalie Huret (3) \\ (1) ONERA,Palaiseau,France, (2) LATMOS, UPMC, Paris,France, (3) LPC2E, Orléans University, Orléans, France
}

Transient Luminous Events (TLE) are electrical and optical events which occurs above thunderstorms. Visual signatures are reported since the beginning of the 20th century but the first picture is accidentally recorded from a television camera in 1989. Their occurrence is closely linked with the lightning activity below thunderstorms. TLEs are observed from the base of the stratosphere to the thermosphere $(15-110 \mathrm{~km})$. They are a very brief phenomenon which lasts from 1 to 300 milliseconds. At a worldwide scale, four TLEs occur each minute. The energy deposition, about some tenth of megajoules, is able to ionize, dissociate and excite the molecules of the atmosphere.

Atmospheric discharges in the troposphere are important sources of $\mathrm{NO}$ and $\mathrm{NO}_{2}$. TLEs might have the same effects at higher altitudes, in the stratosphere. $\mathrm{NO}_{x}$ then can affect the concentration of $\mathrm{O}_{3}$ and $\mathrm{OH}$. Consequently, TLEs could be locally important contributors to the chemical budget of the middle atmosphere.

The perturbation of the atmospheric chemistry induced by TLEs has the consequence to locally modify the radiations in the infrared during the minutes following the event. The interest of studying the infrared signature of a TLE is twofold. For the atmospheric sciences it allows to link the perturbed composition to the resulting infrared spectrum. Then, some Defense systems like detection and guiding devices are equipped with airborne infrared sensors so that the TLE infrared signature might disturb them.

We want to obtain a quantitative and kinetic evaluation of the infrared signature of the atmosphere locally perturbed by a TLE. In order to do so we must model three phenomena. 1) The plasma/chemistry coupling, which describes how the different energetic levels of atmospheric molecules are populated by the energetic deposition of the TLE. This step lasts the time of the lightning itself. 2) The chemical kinetics which describes how these populations will evolve in the following minutes. 3) The radiative transfer which describes the propagation of infrared radiations from the disturbed area to an instrument in a limb line of sight. These three steps must be considered under the assumption of the Non Local Thermodynamic Equilibrium: where TLEs occurs, above $20 \mathrm{~km}$, the populations of the energetic levels are not well described with a Maxwell-Boltzmann distribution. We must consider each excited level as a single species.

In this poster we will present our strategy to simulate the signature of a TLE for different limb line of sights and how we expect to retrieve the atmospheric composition by remote sensing measurement spectra in the framework of the High Altitude Luminous Events Studied by Infrared Spectro-imagery (HALESIS) project and to quantify in which way a TLE can disturb military airborne sensors. 